\title{
Antioxidant Potential and Emulsifying Properties of Kheri (Acacia chundra, Mimosaceae) Gum Polysaccharide
}

\author{
Rishabha Malviya, Pramod Kumar Sharma, Susheel Kumar Dubey
}

\begin{abstract}
Crude Kheri gum (KG) was purified using water as solvent and ethyl alcohol as precipitating agent. Effect of temperature and concentration on the surface tension of KG was determined. Emulsifying properties of gum was evaluated using sunflower oil as oil phase and purified water as continuous phase for further preparations of emulsions which were evaluated in terms of globular size, flow rate, emulsion capacity and emulsion stability, foam capacity and foam stability and creaming(\%). Free radical scavenging properties of polymer was also studied using ascorbic acid as standard against $\mathrm{DPPH}^{1}$ (1,1-diphenyl-2picryl hydrazyl) and $\mathrm{H}_{2} \mathrm{O}_{2}$ as radical. At higher concentration of KG better emulsifying and foaming properties were observed due to the reduction in rate of coalescence and creaming.
\end{abstract}

Globular size of prepared emulsions ranged from 1.4 to $2.6 \mu$. Significant changes in globular size of prepared emulsions were not detected after 45 days. The effective concentration $\left(\mathrm{EC}_{50}\right)$ sufficient to scavenge $50 \%$ of free radical generated using $\mathrm{DPPH}^{1}$ was found to as $36.53 \pm 2.03 \mu \mathrm{g} / \mathrm{ml}$ and $11.09 \pm 3.21 \mu \mathrm{g} / \mathrm{ml}$ for ascorbic acid and $\mathrm{KG}$ respectively. The effective concentration $\left(\mathrm{EC}_{50}\right)$ sufficient to scavenge $50 \%$ of hydroxyl ions generated using $\mathrm{H}_{2} \mathrm{O}_{2}$ was calculated and found as $73.13 \pm 1.98 \mu \mathrm{g} / \mathrm{ml}$ and $53.96 \pm 1.53 \mu \mathrm{g} / \mathrm{ml}$ for ascorbic acid and KG respectively. So, by the help of findings it can be concluded that KG can be used as an emulsifying agent in food, cosmetic and pharmaceutical industry with significant antioxidant potential.

Keywords: Acacia chundra gum ; Kherigum; emulsion; surface tension; antioxidant
Rishabha Malviya, Pramod Kumar Sharma

Polymer Science Laboratory, Department of Pharmacy, School of Medical \& Allied Sciences, GalgotiasUniversity, GreatorNoida U.P., India

Rishabha Malviya

Department of Pharmacy, Uttarkhand Technical University, Dehradun, Uttarakhand, India

Susheel Kumar Dubey

Siddarth Institute of Pharmacy, Dehradun, Uttarakhand, India

\section{Corresponding Author:}

Rishabha Malviya

e-mail: rishabhamalviya19@gmail.com,

rishabha.malviya@galgotiasuniversity.edu.in

Submitted / Gönderilme: 11.01.2017 Revised / Düzeltme: 07.02.2017

Accepted / Kabul: $\quad 08.02 .2017$

\section{Introduction}

Emulsion is a biphasic liquid dosage form to present thermodynamically unstable dispersion of one liquid into another. To improve the stability of emulsions, use of suitable emulsifying agent is prerequisite. Water soluble gums, also known as hydrocolloids are used in food, cosmetic and pharmaceutical preparations to improve stability, appearance and quality. Hydrocolloids are used to reduce surface tension at the interface of globular dispersed phase and continuous phase and provide kinetic stability to emulsion (1). In another words emulsifying agents are employed to prevent coalescence of dispersed globules. Hydrocolloids act as both viscosity enhancer and surfactant and their effectiveness are directly related to their polymer structure and concentration. Hydrocolloids have hydrophilic ends with hydrophobic backbones thus adsorb at oil-water interface. Food industry has placed significant attention for the development of emulsion using gum as emulsifying agents. Industrial manufacturers are keen on developing stable emulsion 
using natural gums and mucilages because of their low cost, ease of availability and biodegradability. As natural polysaccharides reduce surface free energy and increase viscosity of aqueous phase hence can be used as emulsifying agent in pharmaceutical, food and cosmetic industry (2). Natural gums may contain $-\mathrm{COOH}$ and $-\mathrm{CH}_{2} \mathrm{OH}$ groups in their molecular structure. They easily donate $\mathrm{H}^{+}$ions in aqueous phase to neutralize free radicals and can be act as antioxidant $(3,4)$.

Kheri gum (KG) (Acacia chundra (Rottler) Willd. Mimosaceae) is widely distributed in Gujarat, Maharashtra and Rajasthan region of India. Gum obtained from the tree is a good substitute of acacia gum (5).

This study show the case of emulsifying and antioxidant potential of $\mathrm{KG}$ to attract attention of food, drug and cosmetic manufacturers for its possible commercialization. As per our knowledge this is the first manuscript deals with concentration and temperature dependant study of surface tension with emulsifying properties of KG.

\section{Material and Methods}

Crude gum was purchased from local shop of New Delhi India. Gum was authenticated by Prof. D.K. Chauhan, Department of Botany University of Allahabad, Allahabad U P. Crude gum was dissolved in sufficient amount of purified water and heated up to $40^{\circ} \mathrm{C}$. After $2 \mathrm{hr}$ gum solution was filtered through double folds muslin cloth to remove undissolved portion. Gum was precipitated by using ethyl alcohol and dried in oven at $40^{\circ} \mathrm{C}$. Dried gum was powdered, passed through 60 mesh sieve and stored in airtight polypropylene jars under desiccated condition. Phytochemical screening of dried polymer was carried out to identify presence of carbohydrate, protein, volatile oil and fats.

Determination of surface tension: 0.15 to $1 \% \mathrm{w} / \mathrm{v}$ solutions of gum were prepared using distilled water and surface tension was determined using stalagmometer. Effect of temperature on the surface tension was also determined.

Preparation of emulsion: Emulsifying properties of KG was evaluated by formulation of o/w emulsion using sunflower oil as oil phase and KG as emulsifying agent. Initially $90 \mathrm{~mL}$ of gum solutions were prepared using $0.5 \%, 0.75 \%, 1 \% \mathrm{w} / \mathrm{v}$, $1.25 \% \mathrm{w} / \mathrm{v}$ and $1.5 \% \mathrm{w} / \mathrm{v} \mathrm{KG}$ (named F1, F2, F3, F4 and F5, respectively). Further $10 \mathrm{~mL}$ of sunflower oil was added in each solution and homogenized at $5000 \mathrm{rpm}$ for 30 minutes. Prepared emulsions were stored in airtight closed container for further evaluation.
Characterization of emulsions: Prepared emulsions were characterized for following parameters:

Globular size and types of emulsion: Globules size of prepared emulsions was analyzed using optical microscopy (Globus, $\mathrm{Ph} / \mathrm{L} / 16 / 02$ ). Initially magnification value was calculated using coincides point of stage and eye piece micrometer.In this measurement 50 globules in 5 different fields were examined.

Emulsion types were also evaluated using scarlet red as coloring agent.

Viscosity and pH measurement: Viscosity of emulsions was measured using Brookfield viscometer and $\mathrm{pH}$ was determined using digital laboratory $\mathrm{pH}$ meter.

Flow rate: Time required for each emulsion to flow through a $10 \mathrm{~mL}$ pipette was determined and flow rate was calculated using equation 1.

Flow rate $=\frac{\text { volume of pipette }(\mathrm{ml})}{\text { flow time }(\mathrm{s})}$ equation 1

Emulsion capacity and Emulsion stability: Freshly prepared emulsions were transferred in to graduated stoppard measuring cylinder and the emulsifying capacity was calculated using equation 2 .

Emulsion capacity $(\%)=\frac{\text { emulsion volume }}{\text { total volume }} * 100$ equation 2

Emulsion stability was determined to evaluate effectiveness of preparation method (6). After $6 \mathrm{~h}$ emulsion stability was determined using following equation 3

Emulsionstability $(\%)=\frac{\text { final emulsion volume }}{\text { initial emulsion volume }} * 100$ equation 3

Foam capacity and Foam stability: The foaming ability of emulsions was evaluated (7). To determine foaming capacity emulsions were whipped at $10000 \mathrm{rpm}$ for $5 \mathrm{~min}$ with a homogenizer (Ultra Turrax T-25, IKA, Germany). Foam volumes were noted after $10 \mathrm{~s}$ and foam capacity was calculated using equation4:

Foam capacity $(\%)=\frac{\text { initial foam volume }}{\text { total volume of emulsion }} * 100$ equation 4 The reduction of foam volume after 30 min was expressed as foam stability and determined using following equation 5 : Foam capacity $(\%)=\frac{\text { foam volume after } 30 \mathrm{~min}}{\text { total volume of emulsion }} * 100$ equation 5 Determination of creaming: Creaming arte is determined to evaluate stability of prepared sunflower emulsion (2). In this study emulsions were transferred to graduated Stoppard measuring cylinder and stored at room temperature $\left(30^{\circ} \mathrm{C}\right)$. Height of creamed layer was measured at every $24 \mathrm{~h}$ for 21 days. Creaming rate was determined using following equation6: 
Creaming $(\%)=\frac{\text { height of creamed layer }}{\text { original height of emulsion }} \times 100$ equation6

Antioxidant activity: Polysaccharide (KG) backbone contain free - $\mathrm{OH}$ group which can be easily donate proton when ionize in appropriate medium. So it's become necessary to evaluate free radical scavenging properties of polymer. Radical scavenging characteristics of polymer were be evaluated for both $\mathrm{DPPH}^{1}$ and hydroxyl radicals $(8,9)$.

$\mathrm{DPPH}^{1}$ radical scavenging assay: DPPH radical scavenging assay is a standard method to evaluate antioxidant potential of phytochemicals. Scavenging ability of phytochemical was compared with standard antioxidant ascorbic acid. To evaluate antioxidant activity of a compound $0.1 \mathrm{mM}$ solution of $\mathrm{DPPH}^{1}$ was prepared by adding $1.9 \mathrm{mg}$ of $\mathrm{DPPH}^{1}$ in $100 \mathrm{ml}$ volumetric flask and volume was made up with methanol. For the formation of free radicals, solution was kept under dark for $30 \mathrm{~min}$. Sample solutions were prepared in various concentrations viz. 20, 40. 60, 80 and $100 \mu \mathrm{g} / \mathrm{mL}$. Same concentrations of ascorbic acid were also prepared as standards. $1 \mathrm{ml}$ of each sample solution was added with same volume of DPPH'solution, mixed vigorously and kept aside in dark place for $30 \mathrm{~min}$. Absorbances were measured at $517 \mathrm{~nm}(8)$. Same procedure was repeated with standard ascorbic acid solutions. \% scavenging or \% inhibition was calculated using following equation 7 . Tests were performed in triplicate and the graph was plotted with the average of three observations.

$\%$ inhibition (or \% scavenging) = $\frac{\text { (Absorbance of control sample-Absorbance of test sample) }}{\text { Absorbance of control sample }} * 100$...equation 7

$\mathrm{H}_{2} \mathrm{O}_{2}$ radical scavenging activity: In this study hydrogen peroxide was used to form hydroxyl radicals. Standard and sample solutions were prepared as above and concentrations of hydroxyl radicals were evaluated at $230 \mathrm{~nm}$ (9). \% inhibition (or \% scavenging) activity was calculated by using equation 7 . Tests were performed in triplicate and the graph was plotted with the average of three observations.

\section{Results and discussions:}

Water based method was feasible and effective to purify KG. Phytochemical screening of gum shows presence of carbohydrates while lipid, protein, volatile oils and alkaloids are absent in purified polysaccharide.

Surface tension is an important parameter to characterize as natural gums and mucilages are widely using as emulsifying agent in food and pharmaceutical industry. Results showed that as concentration of polymer increases, surface tension decreases (Figure 1).

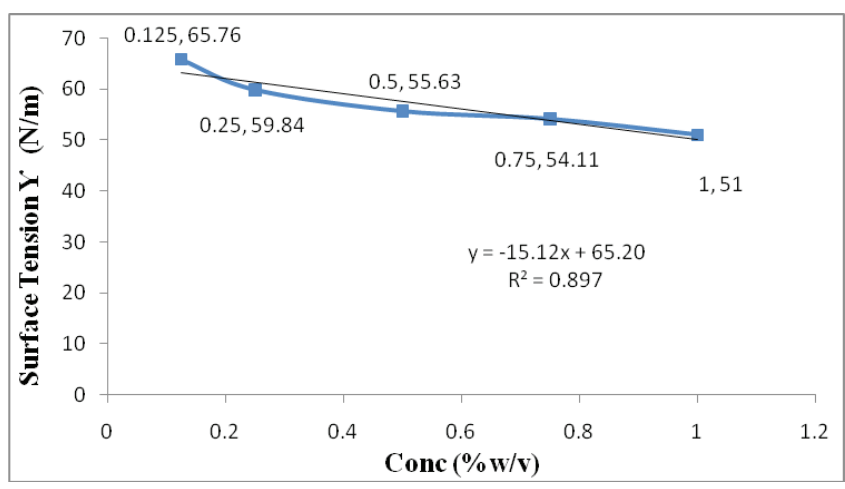

Figure1. Effect of KG concentration on surface tension

Results clearly demonstrate that KG has a significant surface activity. With rise in temperature, the kinetic energy of the molecule increases. Therefore, the strength of intermolecular forces decreases and correspondingly surface tension decreases. Surface activity of KG is due to its hydrophilic nature and absence of any lipophilic substance in purified form such as protein and fat. Thermodynamically emulsions are unstable due to high surface energy (tension) at the contact surface of oil and water molecules and it may leads to complete separation of two immiscible layers by coalescence and creaming. Hydrocolloids reduce surface tension and thickened the aqueous phase.

As shown in Figure 2 temperature has negative effect on surface tension. As the concentration increases, surface tension decreases.

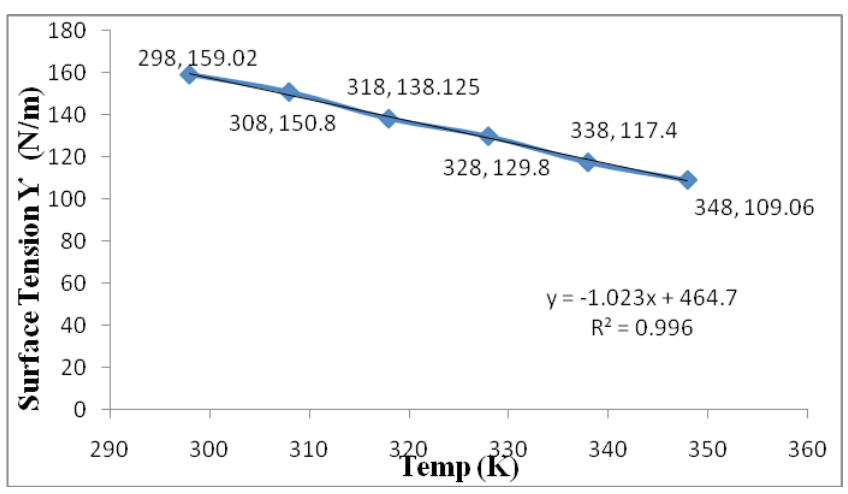

Figure 2. Effect of temperature on surface tension

As shown in Table 1 globular size of prepared emulsions ranged from 1.92 to $3.3 \mu$. During globular size study İt was found that the size increases with the increase in polymer concentration (KG). $\mathrm{pH}$ of emulsions were found in the range of 5.50 to 5.80 and showed slightly acidic nature of formulations. Flow rate of prepared emulsions were found 
to decrease as the concentration of emulsifying agent (KG) increases due to higher viscosity of continuous phase with polymer concentration. It is well known that the higher value of emulsifying agent leads to better and more stable emulsions. This can be proved by the data of emulsion capacity and stability shown in Table 1 .

Natural polysaccharides have good foaming properties and these properties are directly proportional to the concentration of polysaccharide in different formulations (solution, suspension and emulsion). Foaming capacity and stability data are shown in Table 2 to predict the concentration dependant foaming properties of prepared emulsions easily. At higher concentration of KG better foaming properties were observed.

Types of emulsion were identified using scarlet red as coloring agent. Scarlet red is oil soluble dye and red in color. As shown in Figure 3 droplets are appeared as red, so it can be concluded that oil is present as globules (dispersed phase) while water as continuous phase. Hence prepared emulsions were $\mathrm{o} / \mathrm{w}$ in nature.

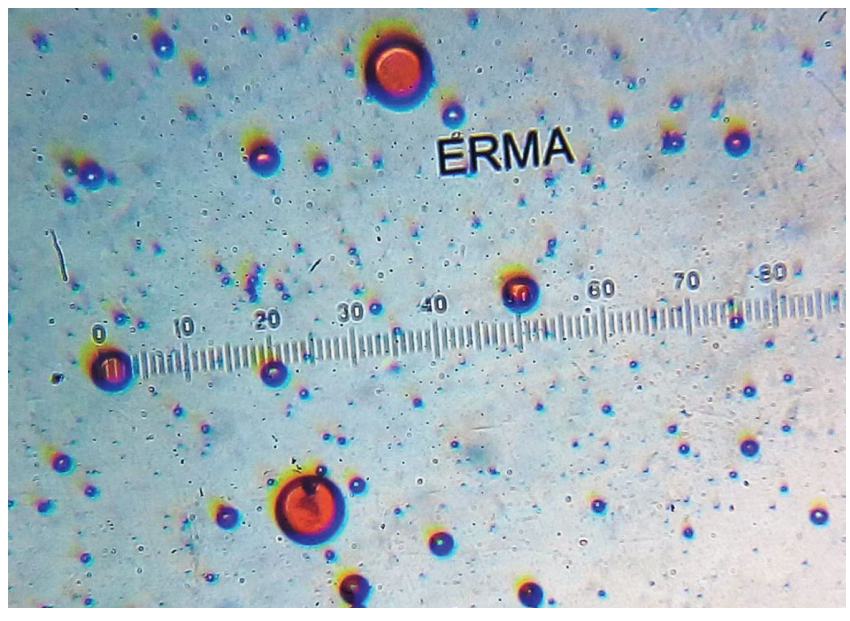

Figure 3. Evaluation of types of emulsion using scarlet red
Emulsifying properties of KG may be due to entrapment of sunflower oil globules into polymeric chain. As the polymer concentration increases globules become more tightly entrapped into polymeric conformation. Higher concentrations of polymer also cause more viscosity which further prevent mobility of globules and delay their coalescence. As described in different studies emulsifying properties of gums are either due to their interface activity $(10,11)$ or viscosity modifying properties which further prevent interaction of globules (1). Polymer imparts good viscosity in aqueous phase which further provides more time to polymer to be absorbed at the interface. Reduction among the droplets' interactions at higher concentration was responsible for slow creaming.

As stated in Stoke's Law, rate of creaming is directly proportional to globular size. Homogenization at high speed leads to formation of smaller droplets hence improve emulsion stability. To prepare stable emulsion, it is advisable to use high speed homogenizer to produce smaller globules.

As described by Stoke's Law, the rate of creaming is inversely proportional to the viscosity of polymer. This characteristics can be proved by creaming studies of formulations. As shown in Table 2 formulations containing higher concentration of KG showed less creaming as compared to formulations with lower KG concentration. Data obtained from different studies also support the gum concentration dependant creaming behavior of emulsions $(12,13)$. Emulsions which were prepared with high concentrations of gum were found to be more stable and remarkable variation in droplet size were not observed. Similar results were also reported by Arash et al (14).

Droplet size measurement is an important parameters to characterize the average droplet diameter of globules in an emulsion and the related data was presented in Table 1 with standard deviation. At low polymeric concentrations

Table 1. Characterization parameters of prepared emulsions

\begin{tabular}{|c|c|c|c|c|c|}
\hline \multirow{2}{*}{$\begin{array}{l}\text { Evaluation } \\
\text { parameters }\end{array}$} & \multicolumn{5}{|c|}{ Formulation } \\
\hline & F1 $(0.5 \% w / v)$ & F2 $(0.75 \% w / v)$ & $\begin{array}{c}\text { F3 } \\
(1.00 \% \mathrm{w} / \mathrm{v})\end{array}$ & $\begin{array}{c}\mathrm{F} 4 \\
(1.25 \% \mathrm{w} / \mathrm{v})\end{array}$ & $\begin{array}{c}\text { F5 } \\
(1.5 \% \mathrm{w} / \mathrm{v})\end{array}$ \\
\hline Globular size $(\mu)$ & $1.92 \pm 14.52$ & $2.4 \pm 13.24$ & $2.6 \pm 21.32$ & $3.1 \pm 19.26$ & $3.3 \pm 20.89$ \\
\hline $\mathrm{pH}$ & $5.51 \pm 0.07$ & $5.55 \pm 0.05$ & $5.57 \pm 0.08$ & $5.58 \pm 0.06$ & $5.63 \pm 0.08$ \\
\hline Viscosity (cPoise) & $0.58 \pm 1.24$ & $0.68 \pm 1.33$ & $0.73 \pm 1.08$ & $0.89 \pm 0.78$ & $1.02 \pm 1.11$ \\
\hline Flow rate $(\mathrm{ml} / \mathrm{sec})$ & $3.5 \pm 0.04$ & $3.1 \pm 0.03$ & $2.6 \pm 0.01$ & $2.2 \pm 0.02$ & $0.91 \pm 0.00$ \\
\hline Emulsion capacity (\%) & $90 \pm 1.47$ & $94 \pm 1.02$ & $96 \pm 2.06$ & $98 \pm 1.49$ & $98 \pm 1.08$ \\
\hline Emulsion stability & $96 \pm 0.82$ & $97 \pm 1.46$ & $98 \pm 1.83$ & $95 \pm 1.46$ & $94 \pm 1.74$ \\
\hline Foaming capacity (\%) & $3.2 \pm 0.41$ & $3.7 \pm 1.06$ & $4.2 \pm 1.59$ & $4.8 \pm 1.83$ & $4.8 \pm 1.67$ \\
\hline Foam stability & $1.97 \pm 0.52$ & $1.98 \pm 0.58$ & $2.01 \pm 1.14$ & $2.31 \pm 1.02$ & $2.77 \pm 1.63$ \\
\hline
\end{tabular}


Table 2. Creaming (\%) of prepared emulsions

\begin{tabular}{|c|c|c|c|c|c|c|c|c|}
\hline \multirow{2}{*}{ Formulation } & \multicolumn{8}{|c|}{ Creaming (\%) } \\
\hline & Afterl day & After 2 days & After 3 days & After 4 days & After 5 days & After 15 days & After 21 days & After 45 days \\
\hline F1 & 0 & 0 & 0 & 0 & 2 & 4 & 4 & 10 \\
\hline F2 & 0 & 0 & 0 & 0 & 2 & 2 & 4 & 8 \\
\hline F3 & 0 & 0 & 0 & 0 & 0 & 2 & 2 & 6 \\
\hline F4 & 0 & 0 & 0 & 0 & 0 & 0 & 2 & 2 \\
\hline F5 & 0 & 0 & 0 & 0 & 0 & 0 & 0 & 2 \\
\hline
\end{tabular}

$(0.5-1 \% \mathrm{w} / \mathrm{v})$, size distribution of droplets did not change significantly during storage and it was revealed from the globular morphology (size and shape) analysis after 45 days (Figure 4). Increase in globular size at higher concentrations (1.25 and $1.5 \% \mathrm{w} / \mathrm{v})$ was mainly due to coalescence and aggregation. It was also observed that no larger droplets increased on storage.

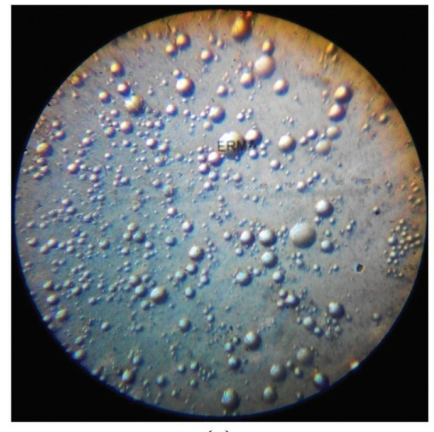

(a)

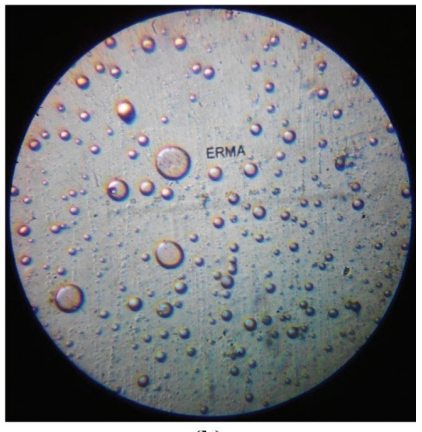

(b)
Figure 4. Particle size analysis of prepared emulsion (F4) (a) at $\mathrm{t}=0$ (b) at $\mathrm{t}=45$ days

$\mathrm{DPPH}^{1}$ has been widely used to evaluate antioxidant activity of various materials obtained from plant and microbial sources. $\mathrm{DPPH}^{1}$ is a chemical that creates free radicals and this radical is further scavenged by antioxidants. This experiment easily shows that KG has compounds that easily scavenge free radicals by donating free hydrogen proton to a free radical in order to remove odd electron, which is responsible for the radical's reactivity. Hydrogen donating properties of polysaccharide can be supported by IR spectra analysis (shows presence of -OH groups). Figure 5 shows that as the concentration of polysaccharide increases scavenging properties of polymer increases. The effective concentration $\left(\mathrm{EC}_{50}\right)$ sufficient to scavenge $50 \%$ of free radical was calculated and found as $36.53 \pm 2.03 \mu \mathrm{g} / \mathrm{ml}$ and $11.09 \pm 3.21 \mu \mathrm{g} / \mathrm{mL}$ for ascorbic acid and KG respectively.

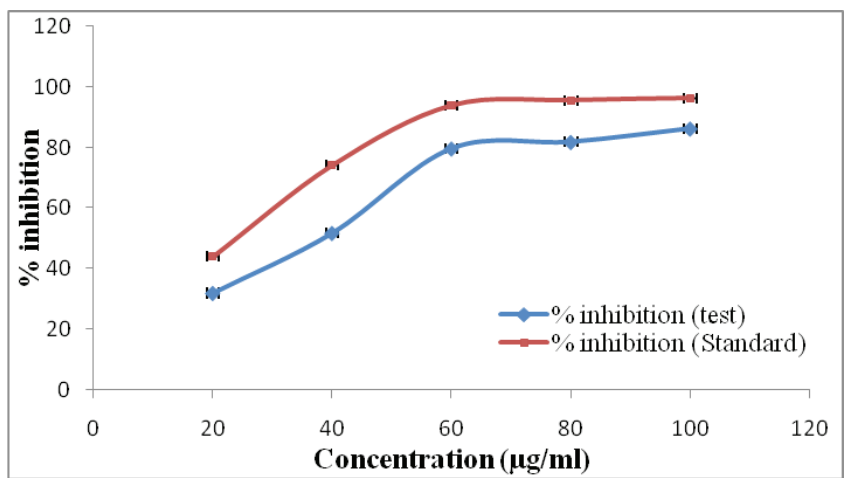

Figure 5. DPPH free radical scavenging activity of KG (ascorbic acid was used as standard)

Figure 6 shows that KG has a hydroxyl group scavenging activity in concentration dependant manner. As the concentration of polymer increases hydroxyl radical neutralizing power of polymer increases. The effective concentration $\left(\mathrm{EC}_{50}\right)$ sufficient to scavenge $50 \%$ of hydroxyl was calculated and found as $73.13 \pm 1.98 \mu \mathrm{g} /$ $\mathrm{mL}$ and $53.96 \pm 1.53 \mu \mathrm{g} / \mathrm{mL}$ for ascorbic acid and $\mathrm{KG}$ respectively.

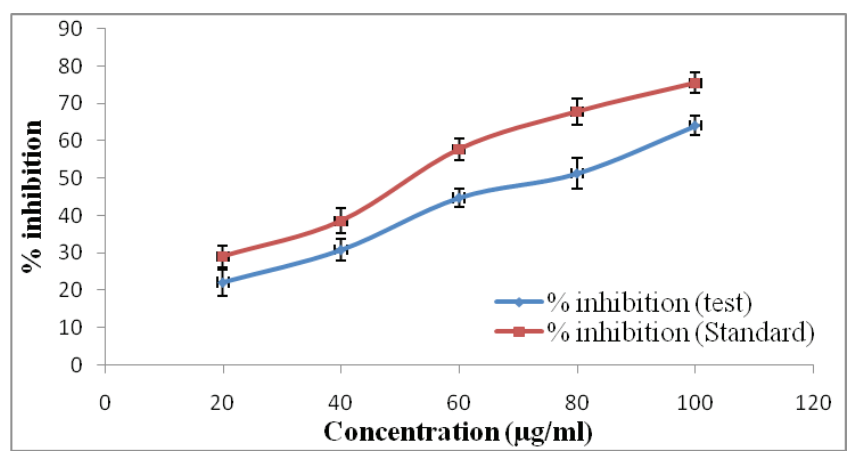

Figure 6. Hydroxyl radicals scavenging activity of KG with standard (ascorbic acid) 


\section{Conclusion}

Natural polysaccharides have been widely used as emulsifying agents in food and pharmaceutical industries. They increase the viscosity of continuous phase and significantly reduce the surface tension. Findings of our studies elicit the fact that KG can be used as an emulsifying agent in biphasic preparations. It also be concluded that KG has a significant antioxidant potential when compared with ascorbic acid. So KG can attract attention of worldwide manufacturera as a substitute of other emulsifying agents. These studies also open new area of research regarding the use of emulsifying agent with antioxidant potential.

Acknowledgement: Authors are thankful to Prof. D.K. Chauhan, Department of Botany University of Allahabad, Allahabad to carry out authentication of plant material.

Conflict of Interest: Authors have no conflict of interest.
Kheri (Acacia chundra, Mimosaceae) reçine polisakkaritinin emülsifiyan özellikleri ve antioksidan potansiyali

\section{ÖZ}

Ham Kheri reçinesi (KG) çözücü olarak su, çöktürme ajanı olarak etil alkol kullanılarak saflaştırılmıştır. Sıcaklığın ve derişimin KG’nin yüzey gerilimine olan etkileri tespit edilmiştir. Reçinenin emülsifiyan özellikleri yağlı faz olarak ayçiçek yağının sulu faz olarak saf suyun kullanıldığı bir emülsiyon sisteminde çalışılmış ve damlacık büyüklügü, akış hız, emülsiyon stabilitesi, köpük oluşturma ve köpük stabilitesi ve kremleşme (\%) parametreleri saptanmıştır. Polimerin serbest radikal süpürücü özelliği radikal olarak $\mathrm{DPPH}^{1}$ (1,1-difenil-2-pikril hidrazil) ve $\mathrm{H}_{2} \mathrm{O}_{2}$ kullanılarak çalışılmış, standart olarak askorbik asit kullanılmıştır. KG’nin yüksek derişimde kullanıldığında daha iyi emülsifiyan etki ve daha yüksek köpüklenme özelliği gösterdiği azalan kaynaşma ve kremleşme hızına bağlı olarak yorumlanmıştır. Hazırlanan emülsiyonların damlacık

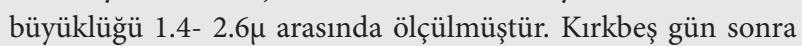
yapılan ölçümlerde emülsiyonların damlacık büyüklüğünde değişme görülmemiştir. DPPH ${ }^{1}$ kullanılarak yapılan deneylerde oluşan serbest radikalleri \%50 oranında süpürmek için yeterli etkili derişim değeri $\left(\mathrm{EC}_{50}\right)$ askorbik asit ve $\mathrm{KG}$ için sırasılyla $36.53 \pm 2.03 \mu \mathrm{g} / \mathrm{ml}$ ve $11.09 \pm 3.21 \mu \mathrm{g} / \mathrm{ml}$ olarak bulunmuştur. $\mathrm{H}_{2} \mathrm{O}_{2}$ kullanılarak yapılan deneylerde oluşan hidroksil iyonlarını \%50 oranında süpürmek için yeterli $\mathrm{EC}_{50}$ askorbik asit ve KG için sırasıyla $73.13 \pm 1.98 \mu \mathrm{g} / \mathrm{ml}$ ve $53.96 \pm 1.53 \mu \mathrm{g} / \mathrm{ml}$ olarak bulunmuştur. Elde edilen veriler işı̆̆ında, KG’nin gıda, kozmetik ve ilaç endüstrisinde antioksidan potansiyali de olan bir emülsiyon ajanı olarak kullanılabileceği düşünülmektedir.

Anahta kelimeler: Acacia chundra reçinesi ; Kheri reçinesi; emülsiyon; yüzey gerilimi; antioksidan

\section{Reference:}

1. Dickinson E. Hydrocolloids at interfaces and the influence on the properties of dispersed systems. Food Hydrocoll 2003;17: 25-39.

2. Verma PRP, Razdan B. Studies on Leucaena lucocephala seed gum: emulsifying properties. Sci Ind Res 2003; 62: 198-206.

3. Malviya R, Sharma PK, Dubey SK. Modifications \& applications of polysaccharides. LAP Lambert Academic Publishing. 2006; 1-60.

4. Malviya R, Sharma PK. Modification of polysaccharides: Pharmaceutical and tissue engineering applications with commercial utility (patents). Mater Sci Eng C 2016, 68: 929938.

5. Punjani B. Ethnobotanical aspects of some plants of Aravalli hills in north Gujarat. Anc Sci Life 2002; 21: 1-16.

6. Naji S, Sayed MAR. Functional and textural characteristics of cress seed (Lepidium sativum) gum and xanthan gum: Effect of refrigeration condition. Food Biosci 2014; 5: 1-8.

7. Jahanbina K, Moinib S, Goharic AR, Emam-Djomehb Z, Masid P. Isolation, purification and characterization of a new gum from Acanthophyllum bracteatum roots. Food Hydrocoll 2012;27: 14-21.

8. Malsawmtluangi C, Thanzami K, Lalhlenmawia H, Selvan V, Palanisamy S, Kandasamy R, Pachuau L. Physicochemical

characteristics and antioxidant activity of Prunus cerasoides D. Don gum exudates. Int J Biol Macromolec 2014; 69: 192-9.

9. Ningsih IY, Zulaikhah S, Hidayat MA, Kuswandi B. Antioxidant activity of various Kenitu (Chrysophyllum cainito L.) leaves extracts from Jember, Indonesia. Agric Agric Sci Procedia 2016; 9: 378-85.

10. Garti N, Madar Z, Aserin A, Sternheim B. Fenugreek Galactomannan as food emulsifiers. Food Sci Technol 1997; 30: 305-11.

11. Garti N, Aserin A. Surface and emulsifying properties of a new gum extracted from Portulaca oleracia L. Food Hydrocoll 1999; 13: 145-55.

12. Sun C, Gunasekaran S, Richards MP. Effect of xanthan gum on physicochemical properties of whey protein isolate stabilized oil-in- water emulsions. Food Hydrocoll 2007; 21: 555-64.

13. Taherian AR, Fustier P, Ramaswamy HS. Effects of added weighting agents and xanthan gum on stability and rheological properties of beverage cloud emulsions formulated using modified starch. J Food Process Eng 2007; 30: 204-24.

14. Koocheki A, Kadkhodoee R, Mortazavi SA, Shahidi F, Taherian AR. Influence of alyssum homolocarpum seed gum on the stability and flow properties of o/w emulsion prepared by high intensity ultrasound. Food Hydrocoll 2009; 23: 241624. 